\title{
NOTES AND SUGGESTIONS ON THE EVIDENCE ACT OF ILLINOIS
}

\author{
JoHn V. McCormrck*
}

STORY is told by a man who was recently appointed to one of the
major legal offices in Chicago. After he had taken possession of his
office, and was gradually becoming acclimated, he went on a tour of inspection, and in the file room found an antique desk resembling as nearly as possible, an old fashioned "high boy." This desk was placed in the very center of the room; each clerk, in order to avoid it, had to make a detour. The desk appeared to be disused. The new incumbent of the office asked the chief clerk if he knew who used the desk, and was informed that no one was using it, nor had it been used in the memory of the speaker. He asked if it was used as a depository for papers, and was informed it was not. He then suggested that the desk had better be moved out, and that suggestion was met with the protest that this could not be done, for the reason that the desk had been there constantly as long as the oldest person in the office could remember.

That seems in many instances to be the situation which exists regarding legal rules, whether statutory or common law, which concern old matter that once became crystallized as a matter of law. Though it involves no question of vested rights and is a marked inconvenience to the judges and practitioners, and a definite obstruction to the path of justice, any suggestion as to its removal or reform will be promptly met by protest both from the bench, the bar, the legislators and the laity that we are attempting to destroy a rule whose only claim for continued existence is that it has been in existence for a period of which the memory of man runneth not to the contrary. In a few cases the courts have, on their own initiative, taken the matter in hand and changed the law without the necessity of legislative action.

Dean Wigmore several times in his work on Evidence called attention to the fact that the American courts inherited from the English the "sporting theory" of the law. The fox hunter felt that the fox was entitled to a run for his life, so in the theory of the law, a criminal should be given a similar law of the field, and in a lesser degree the party opponent, insofar as the law of procedure or evidence might apply. A glaring example of this is the difficulty which attends the proof of agency. It seems that under such circumstances it would aid the administration of justice if one were permitted to prove a prima facie agency, leaving the rebuttal

* Dean of the School of Law, Loyola University. 
to the opponent who would have full access to all the necessary sources of proof. In many cases the law assumes too much of the character of a game of skill and sharpness, and in too many instances the fact is forgotten that the lawyer is an officer of the court, and that the purpose of the courts is not solely to act as umpires in adjusting delicate, quibbling points, and ending causes upon technical errors in pleading and procedure, but that their prime purpose should be the administration of justice, and in a final analysis, that the cause is the client's and not the lawyer's.

The State of Illinois has been blessed or cursed with a particularly vicious example of a leaden headed statutory obstruction to convenient and speedy procedure, and so to proper administration of justice. The Evidence Act of Illinois instead of lightening the obscurity of the rules of evidence, which at best are dark enough, has rather further intensified their gloom. Sec. 5 of the Evidence Act ${ }^{\mathrm{I}}$ as it formerly existed, was apparently an attempt to bring together the common law rule that the wife or the husband were incompetent to testify for or against each other in any case in which they were parties, and the very distinct rule that a privilege existed in favor of the husband and wife in all cases as to the disclosure of facts obtained through or because of the marital relationship. The proviso at the end of this statute was added in $x 874$, together with the exceptions in the Act relating to actions upon insurance policies, and against carriers, and as to transactions had or conducted by a married woman as the agent of her husband. Apparently, the theory underlying the added proviso was that it protected the husband or wife as to the common law privilege, and yet in reality it went considerably further than the common law provided.

The Evidence Act of Illinois applies only to civil cases. There was no

I IIl. Rev. Stat. I935 $\S 5$. Husband and Wife.-Exceptions. No husband or wife shall, by virtue of Section $I$ of this act, be rendered competent to testify for or against each other as to any transaction or conversation occurring during the marriage, whether called as a witness during the existence of the marriage or after its dissolution, except in cases where the wife would, if unmarried, be plaintiff or defendant, or where the cause of action grows out of a personal wrong or injury done by one to the other or grows out of the neglect of the husband to furnish the wife with a suitable support; and except in cases where the litigation shall be concerning the separate property of the wife, and suits for divorce; and except also in actions upon policies of insurance of property, so far as relates to the amount and value of the property alleged to be injured or destroyed, or in action against carriers, so far as relates to the loss of property and the amount and value thereof, or in all matters of business transactions where the transaction was had and conducted by such married woman as the agent of her husband in all of which cases the husband and wife may testify for or against each other, in the same manner as other parties may, under the provisions of this act; Provided, that nothing in this section contained shall be construed to authorize or permit any such husband or wife to testify to any admissions or conversations of the other, whether made by him to her or by her to him, or by either to third persons, except in suits or causes between such husband and wife. 
provision in the Criminal Code or elsewhere in the statutes relating to the testimony of husband or wife in criminal cases, and so the common law in its pristine rigidity applied. The reasoning underlying this rule has been severely justly criticized by Dean Wigmore in his work on Evidence. ${ }^{2}$ The Supreme Court of the United States, without the aid of an act of Congress, changed the rule. ${ }^{3}$ In the last general session of the legislature, two bills which were endorsed by the Chicago Bar Association were introduced in the legislature abolishing the incompetency of husband and wife. ${ }^{4}$

The original bill recommended by the Chicago Bar Association after abolishing the incompetency of husband and wife to testify for or against each other, provided that neither "shall, without the consent of the other during marriage nor afterwards, be permitted to testify to private communications made during marriage by one to the other, except in cases between husband and wife, or where one has acted as the agent of the other"; the advantage of such provision over the bills as finally proposed in legislature, is obvious, and in this instance, at least, it appears that the Bar which had been so frequently criticized because of its inability to move forward, and its hesitancy to espouse reforms moved much more rapidly than the legislature. The legislature refused to pass the bill

${ }^{2} 4$ Wigmore, Evidence $\$ 2227$ et seq. (2d ed. I923).

3 Funk v. U.S., 290 U.S. 37 I, 54 Sup. Ct. 212,78 L. Ed. 369 (I933). Nor can the exclusion of the wife's testimony, in the face of the broad and liberal extension of the rules in respect of the competency of witnesses generally, be any longer justified, if it ever was justified, on any ground of public policy. It has been said that to admit such testimony is against public policy because it would endanger the harmony and confidence of marital relations, and, moreover, would subject the witness to the temptation to commit perjury. Modern legislation, in making either spouse competent to testify in behalf of the other in criminal cases, has definitely rejected these notions, and in the light of such legislation and of modern thought they seem to be altogether fanciful. The public policy of one generation may not, under changed conditions, be the public policy of another. Patton v. United States, 28I U.S. 276, 306, 74 L. Ed. 854, 867,50 Sup. Ct. 253,70 A. L. R. 263 (I930).

4 Ill. Rev. Stat. $1935 \S 5$. In all civil actions husband and wife may testify for or against each other, provided that neither may testify as to any communication or admission made by either of them to the other or as to any conversation between them during coverture, except in actions between such husband and wife, and in actions where the custody or support of their children is directly in issue, and as to matters in which either has acted as agent for the other. Bill Proposed to Amend Criminal Code, Art. XIII, \& 6: In all criminal cases, husband and wife may testify for or against each other; provided that neither may testify as to any communication or admission made by either of them to the other or as to any conversation between them during coverture, except in cases where either is charged with an offense against the person or property of the other, or in case of wife abandonment or where the interests of their child or children are directly involved.

These bills were drafted and introduced by Elmer J. Schnackenberg, a Chicago lawyer, member of the Assembly, with some slight modifications made in conference with the subcommittee of the Chicago Bar Association. 
amending the Criminal Code, but did pass the act governing evidence in civil cases. With reference to the action of the legislature, the diatribe of Jeremy Bentham in 1827 might well apply. ${ }^{5}$

5 Jeremy Bentham, Rationale of Judicial Evidence, bk. ix, pt. IV, c. V. (Bowring's ed. vol. VII, pp. 48I ff. (I843)). " 'Hard,' 'hardship,' 'policy,' 'peace of families,' 'absolute necessity,'-some such words as these are the vehicles by which the faint spark of reason that exhibits itself is conveyed. There are the leading terms, and these are all you are furnished with; and out of these you are to make an applicable, a distinct and intelligible proposition, as you can. . . . . (As to the 'policy' of the situation, it is precisely the opposite; for) if a man could not carry on schemes of injustice without being in danger, every móment, of being disturbed in them, and (if that were not enough) betrayed and exposed to punishment by his wife, injustice in all its shapes, and with it the suits and the fees of which it is prolific, would, in comparison with what it is at present, be rare. Let us, therefore, grant to every man a license to commit all sorts of wickedness in the presence and with the assistance of his wife; let us secure to every man in the bosom of his family, and in his own bosom, a safe accomplice; let us make every man's house his castle, and, as far as depends upon us, let us convert that castle into a den of thieves! Two men, both married, are guilty of errors of exactly the same sort, punishable with exactly the same punishment. In one of the two instances (so it happens) evidence sufficient for conviction is obtainable, without having recourse to the testimony of the wife. While the one suffers-capitally, if such be the punishment,-to what use, with what consistency, is the other to be permitted to triumph in impunity? . . . A rule like this, protects, encourages, inculcates fraud. For falsehood, positive falsehood, is but one modification of fraud; concealment, a sort of negative falsehood, is another; I mean concealment of any facts of which, for the protection of their rights, individuals or the public have a right to be informed. . . . By authorizing an individual to conceal it, in a case in which it is not so much as pretended that its mischievousness is in the smallest degree less than in other cases, it at once protects and encourages two different acts, of the mischievousness and criminality of which it shows itself sufficiently sensible on other occasions; - the principal crime, and that concealment of it, which, when the act so concealed is criminal, is itself a crime. . . . (As to the danger of 'dissension') if the dissension were, in the nature of the case, so implacable as the argument supposes, it should consistently speaking, operate as a motive with the law to prescribe, rather than exclude this source of information. 'If I attempt this crime, it may happen to my wife, from whom I cannot hope to conceal it, to be called upon to bear witness against me; and then,- - even if I should escape from the punishment of the law, - the pain of seeing, in the partner of my bed, the once probable instrument of my destruction, will never leave me. .... Oh! but think what must be the suffering of my wife, if compelled by her testimony to bring destruction on my head, by disclosing my crimes! - 'Think?' answered the legislator: 'Yes, indeed, I think of it; and in thinking of it, what I think of besides, is, what you ought to think of it. Think of it as part of the punishment which awaits you, in case of your plunging into the paths of guilt. The more forcible the impression it makes upon you, the more effectually it answers its intended purpose. Would you wish to save yourself from it? It depends altogether upon yourself; preserve your innocence!' To the legislators of antiquity the married state was an object of favor; they regarded it as a security for good behavior; a wife and children were considered as being (what doubtless they are in their own nature) so many pledges. Such was the policy of the higher antiquity. The policy of feudal barbarism, of the ages which gave birth to this immoral rule, is to convert that sacred condition into a nursery of crime. The reason now given was not, I suspect, the original one. Drawn from the principle of utility, though from the principle of utility imperfectly applied, it savors of a late and polished age. The reason that presents itself as more likely to have been the original one is the grimgribber non-sensical reason,- that of the identity of the two persons thus connected. Baron and Feme are one person in law. On questions relative to the two matrimonial conditions, this quibble is the fountain of all reasoning." 
The section of the Evidence Act dealing with book accounts is equally objectionable. ${ }^{6}$ Originally there were two rules with reference to the introduction of account books ${ }^{7}$ which prevailed in the United States courts, one known as the New England rule, the other as the New York rule. Under the New York rule there was a requirement that in order to lay a foundation for the introduction of an account book it was necessary for the proponent to prove that the entry therein had been made in the original course of business by a person whose duty it was to make it, and it was also necessary that some proof be made of the correctness of the account, such as that other persons had settled, by the account book, or that some of the goods had actually been delivered. In spite of the fact that the terms of the statute in Illinois do not seem to require the same type of proof under the New York rule as was required before the passage of the statute, the Supreme Court of Illinois has held that the statute has not taken the place of the common law. ${ }^{8}$ A draft of a law was proposed by the Commonwealth Fund Committee on Legal Research, which would simplify the admission of account books or any written memorandum of record.9 This Act is in force in New York and seems to have worked satisfactorily. ${ }^{10}$ This suggested bill to take the place of Sec. 3 of the Evidence Act of Illinois is now under consideration by the Committee on Amendment of Law of the Chicago Bar Association.

${ }^{6}$ Ill. Rev. Stat. I935 $\$ 3 .-B o o k$ account-Preliminary proof. Where in any civil action, suit or proceeding, the claim or defense is founded on a book account, any party or interested person may testify to his account book, and the items therein contained; that the same is a book of original entries, and that the entries therein were made by himself, and are true and just; or that the same were made by a deceased person, or by a disinterested person, a nonresident of the state at the time of the trial, and were made by such deceased or non-resident person in the usual course of trade, and of his duty or employment to the party so testifying; and thereupon the said account book and entries shall be admitted as evidence in the cause.

7 Radtke v. Taylor, to5 Ore. 559, 210 Pac. 863 (rg22).

${ }^{8}$ House v. Beak, I4x Ill. 290 ( 1893 ).

- Some proposals for reforms of the law of Evidence. Report by Commonwealth Fund Committee on Legal Research: Any writing or record, whether in the form of an entry in a book or otherwise, made as a memorandum or record of any act, transaction, occurrence or event shall be admissible in evidence in proof of said act, transaction, occurrence or event, if the trial judge shall find that it was made in the regular course of any business, and that it was the regular course of such business to make such memorandum or record at the time of such act, transaction, occurrence or event or within a reasonable time thereafter. All other circumstances of the making of such writing or record, including lack of personal knowledge by the entrant or maker, may be shown to affect its weight, but they shall not affect its admissibility. The term business shall include business, profession, occupation and calling of every kind.

${ }^{20}$ New York Civil Practice Act $\$ 374$ (a) (I93I). 